\title{
The Metaphysics of the Incarnation in the Summa Halensis and its Place in the Later History of Christology
}

\begin{abstract}
The aim of this chapter is not to give a complete overview of the Summa's understanding of the metaphysics of Christology. Rather, the goal is to focus on the most distinctive claims to be found in the text, and to try to show what effect they had on the later tradition up to William of Ockham. That said, the two most distinctive claims that the text makes also turn out to be on the two topics most central to an account of the metaphysics of the Incarnation: that is to say, the nature of the union between the natures, and the nature of subsistence - why it is that the human nature does not itself count as a subsisting person. This chapter deals with the two topics in turn, and then shows how the Summa's insights were developed (and sometimes rejected) in its three most important readers: Aquinas, Bonaventure, and Scotus.
\end{abstract}

\section{The Christology of the Summa Halensis}

\section{Varieties of Union}

Alexander's Glossa takes as its metaphysical starting point Alan of Lille's attempt in his Regulae theologiae to situate the hypostatic union in a general taxonomy of the kinds of union - one which Alan seems to have based on a reading of Aristotle, De generatione et corruptione I, chapter 10. The Summa follows it closely, using the classification as an account of the ways in which, as the Summa puts it, things can be 'substantially one'. ${ }^{1}$ Alan distinguishes cases of aggregation (appositio) from non-aggregative unions. Aggregative unions are such that the things collected together 'do not make one thing,' and such that 'there is no composition from them.' ${ }^{2}$ Aggregations are divided into four sorts: those in which there is neither shar-

1 See Alexander of Hales, Doctoris irrefragabilis Alexandri de Hales Ordinis minorum Summa theologica (SH), 4 vols (Quaracchi: Collegium S. Bonaventurae, 1924-48), IV, In1, Tr1, Q4, Ti2, C1 (n. 57), Solutio, p. 83a. Much of Alan's text is quoted verbatim in Alexander of Hales, Magistri Alexandri de Hales Glossa in quatuor libros Sententiarum Petri Lombardi (Quaracchi: Collegium S. Bonaventurae, 1954), vol. III, d. 7, n. 6, p. 96; in the second redaction it is ascribed (wrongly) to Gilbert of Poitiers: Glossa III, d. 7, n. 19, p. 96 (suggesting that Alexander was not aware of its ultimately Aristotelian origin). 2 Alan of Lille, Regulae theologiae, c. 100, n. 1, in N.M. Häring (ed.), 'Magister Alanus de Insulis, Regulae caelestis iuris,' Archives d'histoire doctrinale et littéraire du moyen âge 48 (1981), pp. 97-226, on p. 205. 
ing of properties nor the denomination of one by the other; ${ }^{3}$ those in which there is sharing of properties; ${ }^{4}$ those in which there is denomination; ${ }^{5}$ and those in which one predominates over the other such that the other is 'absorbed by it." (Alan's examples of each: two stones next to each other; a hand taking on the scent of an apple that it is grasping; a man wearing a cloak [thus becoming a 'cloaked man']; and a drop of wine poured into the Seine - of which only the Seine survives.) I assume that cases in which one of the components gains both property and denomination from the other would count as one of the non-aggregative unions outlined next in the discussion. Such unions, indeed, are in turn divided into three kinds: mixtures, in which the components are destroyed and a third kind of thing produced $;{ }^{7}$ cases in which the union results in a third thing without the components being destroyed; ${ }^{8}$ and cases in which one thing is made to belong to another. ${ }^{9}$ (Alan's examples: a mixture of water and honey, in which [supposedly] neither the water nor the honey survives; body and soul resulting in a human being; and 'a shoot united to a tree by grafting [insitionem], through the medium of heat and a humor.') The last of these best models the Incarnation:

The body and soul are united to the Son of God, not such that they are the Son of God, but instead such that they belong to the Son of God; and not such that the Son of God consists of them along with something else; but the two natures are in the one person, the divine [nature] remaining divine and the human remaining human. ${ }^{10}$

So here the human nature is united to the Son of God by being made to belong to him in the relevant way. As far as I know, incidentally, this is the first case in which the instance of grafting is used as a model for the Incarnation.

The Summa follows this analysis closely, tidying up details as it goes. Cases of substantial unity are divided into two broad kinds, simpliciter and secundum quid. The latter correspond to Alan's aggregations, divided into three kinds: cases in which one component gains neither property nor denomination from the other; cases in which the one gains property but not denomination from the other; and cases in which the one gains denomination but not property from the other. ${ }^{11}$ (Examples of each: two stones in a heap [acervo]; 'an apple or something aromatic in the hand' - the hand gains a property of the apple without being an apple; and someone

3 Alan of Lille, Regulae, c. 100, n. 1 (Häring, p. 205).

4 Alan of Lille, Regulae, c. 100, n. 2 (Häring, p. 205).

5 Alan of Lille, Regulae, c. 100, n. 2 (Häring, p. 205).

6 Alan of Lille, Regulae, c. 100, n. 4 (Häring, p. 205).

7 Alan of Lille, Regulae, c. 100, n. 5 (Häring, p. 206).

8 Alan of Lille, Regulae, c. 100, n. 6 (Häring, p. 206).

9 Alan of Lille, Regulae, c. 100, n. 7 (Häring, p. 206).

10 Alan of Lille, Regulae, c. 100, n. 7 (Häring, p. 206).

11 SH IV, In1, Tr1, Q4, Ti2, C1 (n. 57), Solutio, p. 83a. 
clothed. ${ }^{12}$ ) There are four ways in which two things can be one simpliciter. Two such ways are incompatible with the survival of both components: either one is destroyed (and the other preserved - a particular case of predominance), or, contrariwise, both are destroyed. The remaining two ways require the preservation of both components' natures: first, cases in which the two components constitute a third thing distinct from themselves; and, secondly, cases in which they fail to do so, such that the one is made to be 'of (de) the other' - according to the Summa, another kind of predominance. ${ }^{13}$ (Examples of each: a large amount of wine mixed with a small amount of water - of which only the wine survives; a mixture of water and honey; the union body and soul resulting in a human being; and the case in which 'a shoot of pear is united to a tree in which it is grafted, be it an apple or other [tree].')

The taxonomy is neater than Alan's: in particular, the predominance case is far better thought of as a case of union simpliciter: one substance results, after all; and, equally, it does not really seem plausible to think of such cases - in which, after all, one of the substances does not survive - as a case of the aggregation or apposition of two substances. Equally, the Summa makes clear what Alan's view presupposes but does not make explicit: that the relevant grafting case must involve two distinct species if it is to model the Incarnation. Indeed, the Summa goes into much more detail on the crucial cases:

In grafting, the predominant [component] draws (trahit) the other to its unity, such that [the latter] is of it, but is not it. So in the union in which [just] one [component] is altered, there is a union in the one which draws the other to its nature. In the union in which both are altered, there is a union in a third - that is, a third nature - which third is effected or confected from them. But in the union in which one is of the other, as in a union by grafting, there is a union in one hypostasis, such that there is one hypostasis of two natures. Hence after they are united by grafting there is, of the pear and the apple grafted onto the same trunk, the same hypostasis - that is to say, the same tree - which has two utterly different natures, and there is one hypostasis, not [one] nature. ${ }^{14}$

The idea is that the apple-pear hybrid has two natures while remaining just one tree. I assume that the trunk should be either that of what is predominantly an apple tree or predominantly a pear tree, else there would be no explanation of the way in which the one 'draws the other to its unity': there would, in other words, be no explanation of the way in which the tree itself persists through the change.

The applicability of the model is likewise spelled out with considerable precision (albeit with a rather fanciful bit of scriptural exegesis, added by the authors of the Summa to their two sources):

12 SH IV, In1, Tr1, Q4, Ti2, C1 (n. 57), Solutio, p. 83a-b.

13 SH IV, In1, Tr1, Q4, Ti2, C1 (n. 57), Solutio, p. 83b.

14 SH IV, In1, Tr1, Q4, Ti2, C1 (n. 57), Solutio, pp. 83a-84b. For the grafting example, see too Odo Rigaldus, In Sent. III, d. 7 (MS Bruges, Openbare Bibliotheek, lat. 208, fol. 372ra). 
In this way it should be said (...) that the union of the humanity to the deity is that in which one is of the other, and not that in which one is the other or in which one thing (namely, a third), is from them. So Blessed James (1:21) says 'Receive with meekness the engrafted Word,' that is, the Son of God united to the human nature. And since the divine person is predominant in this union, it draws (trahit) the human nature to the unity of its hypostasis. So the human nature is not a part of the divine person, but is of him, since there is one hypostasis of each [nature], and the integrity of each nature is preserved. ${ }^{15}$

Elsewhere, the Summa speaks of this unity in terms of a relationship of the human nature to the divine esse: the human nature is grafted into the Word such that he draws (trahit) the human nature to the esse of his hypostasis, and that [the nature] is of his hypostasis as a pear is of the hypostasis of the apple [tree], while the nature of a pear is not the nature of an apple. ${ }^{, 16}$ And, slightly less clearly, 'the human nature goes (transit) from divine non-esse to divine esse (de non-esse divino ad esse divinum) by union with the Word in one person and in the one esse of the person. ${ }^{17}$ Unfortunately, the Summa does not develop an account of esse such that these suggestions could provide any real way of understanding the mechanics of the hypostatic union.

Both of these cases (grafting and incarnation) involve an action - uniting. In the Aristotelianism of the Summa, actions have corresponding passions: 'to assume is like an action, and to be assumed like a passion. ${ }^{, 18}$ In his discussion of the grafting case, Alan of Lille offers some detail on the relevant process: it is brought about by means of the heat and humors of the tree. The Summa does not bother with the natural case. But it asks a rather deeper question about the supernatural case: is it immediate, not (of course) in the sense of having no efficiently causal explanation, but in the sense of lacking any formal explanation over and above the things united which is to say, the divine person and the human nature? The Summa distinguishes between a 'medium of necessity' and a 'medium of congruity'. The former 'ties the extremes'; ${ }^{19}$ the latter 'implies an order in the extremes. ${ }^{20}$ It is the first that is of interest here: 'If we speak of a medium of necessity between the uncreated spiritual substance that is the deity and the corporeal created [substance] in Christ, there was no medium. ${ }^{21}$ In line with this, the Summa maintains that what ties the natures in Christ is simply the divine person ('the person binds and ties [vincit et ligat] the natures'). ${ }^{22}$ And not only is there no created relation between the two natures; there is no created relation between the human nature and the divine person either:

15 SH IV, In1, Tr1, Q4, Ti2, C1 (n. 57), Solutio, p. 84a.

16 SH IV, In1, Tr1, Q4, Ti2, C7, Ar2 (n. 64), Solutio, pp. 94b-95b.

17 SH IV, In1, Tr1, Q4, Ti2, C7, Ar1 (n. 63), Ad obiecta 3, p. 93b.

18 SH IV, In1, Tr1, Q4, Ti1, D1, C1 (n. 30), Ad obiecta 5, p. 49b.

19 SH IV, In1, Tr1, Q4, Ti1, D1, C3 (n. 34), Respondeo, p. 53a.

20 SH IV, In1, Tr1, Q4, Ti1, D1, C3 (n. 34), Respondeo, p. 53b.

21 SH IV, In1, Tr1, Q4, Ti1, D1, C3 (n. 34), Respondeo, p. 53b.

22 SH IV, In1, Tr1, Q4, Ti2, C6 (n. 62), Ad quod sic c, p. 90a. 
When it is said that this tree is united to a shoot, we can consider this tree both as a thing of a nature (res naturae) and as an individual (...). And as it is a thing of a nature, it is in this way the extreme of the union; but as it is an individual, in this way it is the medium of the union, because in this way it is that in which the union is made, for this thing, that is, the tree, is united to the shoot in individuality or in hypostasis. Likewise, the Son of God, understood as a thing of nature, is the extreme of this union; but as he is a person, in this way he is the medium of that union, because the Word is united to the human nature in person. ${ }^{23}$

What the Summa here argues is that there is a tie between the human nature and the divine nature (that is to say, 'the Son of God understood as a thing of nature'): and that tie is simply the Son of God himself. But there is no further tie - for example, between the Son of God and the human nature.

The position has the odd but natural consequence that the Son of God is both the end term of the relation (to the human nature) and the relation itself - a view that the Summa takes from Odo Rigaldus:

To (...) the argument in which it is objected that nothing is terminated on itself, it should be said that this is true [of a thing understood] under the same description (...). But it should be said that the person who is the Son of God, as he is a thing of a nature, is in this way the end term of the union; but as he is a person, in this way is the medium and the end term of the union, and thus he is terminated on himself, but under a different description (differt secundum rationem). ${ }^{24}$

The Son of God, considered as being the same as the divine nature, is the end term of the relation; but considered as that item in which the natures are united, he is himself the relation or tie between the natures.

Elsewhere the Summa expresses the immediacy of the union between person and nature by means of a rather striking metaphor: 'The union of the Word to the flesh does not bring about a change in the Word, but there is a change merely in the humanity, which now receives the "ray" of divinity and previously did not. For this reason, there is no change in the eternal light. ${ }^{25}$ The human nature is in immediate contact with the 'light' that is the Word. The text talks of the reception of a 'disposition' in this context; but, evidently, all that it means is that the nature is changed by its contact with the Word: it is now true that it is immediately united to the esse of the Word; prior to the assumption, it was not true. ${ }^{26}$

The grafting model, as appealed to by the Summa, has a crucial limitation. It does, after all, rely on a certain kind of physical or biological process, and it is questionable whether much sense of it can be made outside that context. As we shall see,

23 SH IV, In1, Tr1, Q4, Ti2, C1 (n. 57), Ad obiecta 2, p. 84b.

24 SH IV, In1, Tr1, Q4, Ti2, C1 (n. 57), Ad obiecta 3, p. 84b; see Odo Rigaldus, In Sent. III, d. 6 (MS OBB lat. 208, fol. 368vb).

25 SH IV, In1, Tr1, Q4, Ti2, C7, Ar1 (n. 63), Solutio, p. 93a.

26 For the view that there is a change in the human nature but not in the Word, see Odo Rigaldus, In Sent. III, d. 6 (MS OBB lat. 208, fol. 369va). Rigaldus seems to be a source here for both the Summa and for Bonaventure. 
the theologian who follows the Summa most closely - that is to say, Thomas Aquinas - provides a metaphysical framework that goes some considerable way towards mitigating this worry.

\section{The Nature of Subsistence}

Another distinctive feature of the Summa that turned out to be highly significant in the later development of Christology is its discussion of the nature of subsistence. It is fair to say that the Summa faces in two distinct directions on this topic. The understanding of the nature of subsistence changed radically in the mid-13th century, away from older, juridical, notions, and towards a more metaphysical focus. ${ }^{27}$ The Summa nicely combines both, and was doubtless significant in helping to foster the change if only, perhaps, as a rather negative example.

The Summa paraphrases Richard of St Victor's definition of 'person', but argues that it is, properly speaking, the definition not of 'person' but of 'hypostasis': 'hypostasis is an existence or substance, incommunicable in virtue of certain kinds of distinguishing features (hypostasis [...] est existentia vel substantia incommunicabilis ex quibuscumque distinguentibus). ${ }^{28}$ The notion of person adds two further notes: 'A person, both according to the reality and the name of "person" is an incommunicable rational substance, distinct by a property of dignity. ${ }^{29}$

A number of things emerge that are worthy of comment. First of all, the authors of the Summa evidently hold that properties have a role in individuation: "IIndividual" is said in two ways: first, individual substance, which is of itself divided from all others; and, secondly, something that has a collection of properties that is never the same in anything else. ${ }^{30}$ And this latter sense is what explains incommunicability, as we learn from the definition of 'hypostasis' just given. In the same article, we learn that paradigm cases of communicability involve being part of, or united to some further substance (e.g. soul, as joined with a whole human being, ${ }^{31}$ or Christ's human nature as joined to the Word). ${ }^{32}$ Furthermore, personhood adds two further features to hypostasis: being rational, and having a 'property of dignity'.

Elsewhere, the authors give us an explicit account of these three features (singularity, incommunicability, dignity; for ease of reference I number the Sentences):

27 On this, see Theo Kobusch, Die Entdeckung der Person: Metaphysik der Freiheit und modernes Menschenbild (Freiburg; Basel; Vienna: Herder, 1993).

28 SH IV, In1, Tr1, Q4, Ti1, C3, Ar3 (n. 52), Solutio, p. 76a.

29 SH IV, In1, Tr1, Q4, Ti1, C3, Ar3 (n. 52), Solutio, p. 76b.

30 SH IV, In1, Tr1, Q4, Ti1, C3, Ar3 (n. 52), Solutio, p. 76b.

31 SH IV, In1, Tr1, Q4, Ti1, C3, Ar4 (n. 53), Ad quod sic 5, p. 77b.

32 SH IV, In1, Tr1, Q4, Ti1, C3, Ar4 (n. 53), Ad obiecta 5, p. 79a. 
1. For the esse of a person there is required a three-fold distinction, namely, of singularity, of incommunicability, and of dignity. 2. The distinction of singularity is in a soul while it is in a body: for it is separate (distans) from any other soul by a singular property. 3. The distinction of incommunicability is what some singular has, such as this animal, an ass; but a soul existing in a body does not have this, because it and the body communicate in constituting one esse. 4 . The distinction of dignity is that by which a human being is precisely distinguished from any other [kind]: by individual rationality (qua purus aliquis homo distinguitur ab alio rationalitate individuali), which is the property with the greatest dignity (dignissima proprietas), because, as Boethius says, "the name "person" is suitable for substances of greater dignity. ${ }^{33}$

2. To be singular is, as in the first discussion, to be 'separate' from other instances of the same kind. 3. To be incommunicable is not to share with another in the constitution of a third. 4. And the distinction of dignity is, at least prima facie, rationality. But the discussion is a bit misleading, because it turns out that the distinction of dignity is in fact to have whatever in a particular thing is its highest property. And it turns out too that the incommunicability criterion is understood rather precisely, as we shall see, and in such a way as to render the application to Christology prima facie rather surprising (again, I number the Sentences for ease of reference):

1. For the esse of a person is required this three-fold distinction: of singularity, of incommunicability, and of dignity (which is applied according to the property of the greater dignity). 2. We should say therefore that the first distinction - namely, of singularity - is in the soul of Christ, and also in the body. 3. The first and second are in the composite of soul and body, which is denoted when I say 'this man', pointing to the composite of soul and body - that is, the singular. 4. The first, second, and third are in Christ the God-man. 5. And although he can have the first and second from the human nature, he can have the third only by reason of the divine person, and thus, in Christ, to be a person is not by reason of the human nature. 6. For the notion of person is taken from the more excellent property, with the greater dignity. 7. But the property in Christ with the greater dignity belongs not to the human nature but to the divine person. 8. For this reason it follows that there is no assumption of a person. 9. For the distinction of persons should be according to that which is found to be most noble in the persons. 10. Since, therefore, because in the assumed man it is most noble to be the Son of God, it follows that personal distinction is in him in virtue of his being one person with the Son of God. ${ }^{34}$

2. Both Christ's soul and body are singular, separate from bodies and souls. But 3. they are not incommunicable, since they come together to constitute some further thing - Christ's human nature. This human nature is incommunicable, since (presumably) it does not come together with anything to constitute a third. (I comment

33 SH IV, In1, Tr1, Q4, Ti1, D1, C4 (n. 35), Solutio, p. 55a, summarizing Boethius, Contra Eutychen et Nestorium, c. 2, in Boethius, De consolatione philosophiae; Opuscula theologica, ed. Claudio Moreschini, Bibliotheca scriptorum graecorum et romanorum Teubneriana (Munich; Leipzig: K.G. Saur, 2000), pp. 212-14.

34 SH IV, In1, Tr1, Q4, Ti1, D1, C4 (n. 35), Solutio, p. 55a-b. For the view that the nature is singular and incommunicable, but lacking in highest dignity, see Odo Rigaldus, In Sent. III, d. 5 (MS OBB lat. 208, fol. 366ra). 
on its designation here - 'this man' - in a moment.) And 4-5. the person has both singularity and incommunicability in virtue of his possession of a singular and incommunicable nature. But 6-7. he has dignity from his person as such - for which reason 8. the human nature does not count as a person.

On the face of it 10., the question is this: in virtue of what is the assumed man a person? But this way of talking (of an assumed man) while traditional, is misleading - as is referring to the assumed nature as 'this man' (see 3. above). What is really at stake is this: in virtue of what is the man (Christ, the God-man) a person? And the answer is that he is a person in virtue of whatever is highest in him - that is to say, being the Son of God. In which case, the argument goes, it cannot be the case that a person was assumed..$^{35}$ Overall, then, the line of reasoning about dignity goes like this. Something is a person in virtue of whatever is their highest property. In standard human cases, it is rationality. But in the case of Christ it is the Son of God. So it is in virtue of the being the Son of God (and not, say, of rationality) that Christ is a person.

Compared with the later discussions that I outline in the remainder of this essay, these distinctions are rather messy. In particular, the incommunicability criterion seems to be too restrictive: we would expect incommunicability, I think, to entail that the human nature lacks incommunicability (precisely because it is drawn to the esse of the Word, and thus seems to be a paradigm case of something that would be communicated to another). So the Summa's authors seem to suppose that communication requires at least one of the following two features: jointly 'constituting one esse', with another; or constituting one thing distinct from either of the components - both of which are satisfied in the body-soul case. And neither is satisfied in the Christological case, since (as we have seen) the only communication is from the Word to the human nature (just as the only communication in the grafting case is from the tree to the shoot); and the human nature and the Word do not constitute something distinct from the Word (just as a tree and a shoot do not constitute something distinct from the tree). An odd by-product of this discussion is the claim that a shoot, grafted or not, is both singular and incommunicable.

The Summa makes one further innovative claim that turns out to be important in later debates - and, furthermore, one which seems inconsistent with the notion of incommunicability as thus far adumbrated. An objection explores this notion in the following way:

If it is said that person includes in itself incommunicability with another, either this should be understood according to act or according to power (potentiam). If according to act, then the soul separated from the body would be a person. If according to power, then no human being will be a person, since each could be united to God in person. ${ }^{36}$

35 For the issue, see $S H$ IV, In1, Tr1, Q4, Ti1, D1, C4 (n. 35), Solutio, p. 55 a. 36 SH IV, In1, Tr1, Q4, Ti1, C3, Ar4 (n. 53), Ad quod sic 5, p. 77b. 
Actual incommunicability is failing de facto to be communicated to something else. If this is sufficient to make a rational individual a person, then the soul will be a person. Incommunicability 'according to power' is necessarily failing to be communicated to something else. If this is the mark of personhood, then no human being is a person, since any human being is possibly communicated to the divine person, by being assumed.

Here the notion of incommunicability is taken to be incompatible with being hypostatically united to the divine person - in line with what I take to be later usage (something I explore in subsequent sections of this paper). The reply does not query this, but seems rather to assume it:

'Incommunicability', in the definition (ratione) of 'person' is said not only by the privation of the act, but also by the privation of an aptitude or disposed potency: but not by the privation of a first potency - as Augustine says, that 'in the rib there was that from which could be made a woman, but not that from which she was made ${ }^{37}$ - which is to say, that there was a potency which is in every creature - namely, an obediential potency (possibilitas obedientiae) such that the creator can make from [the creature] whatever he wants - but that there was not there an aptitude or disposed potency. Hence it is that, since in human beings and angels there is no aptitude to union with the Son of God or with something else, there is in them the incommunicability which is required for being a person. ${ }^{38}$

Perhaps in this inconsistency we see signs of the Summa's status as a committee document.

But still, setting aside worries about the coherence of the two accounts of incommunicability (and, indeed, the perhaps dubious reading of Augustine), the clarification offered here is important. The idea is that any human nature is possibly communicated to the divine person (as the objection supposes): it has an 'obediential potency' such that God 'can make from the creature whatever he wants' - including supernatural actions such as assuming the nature hypostatically. (The Summa does not make this explicit, but clearly its definition of 'person' requires that any such assumed nature would cease, on assumption, to be a person. As we shall see, this point is made explicitly by Duns Scotus sixty years later, building on and clarifying what is set out in the Summa.) But not only is actual incommunicability required for being a person; so too is an inclination for incommunicability. Persons are naturally such unless prevented by some supernatural divine activity (such as assumption, as in the case of Christ's human nature). Thus they lack 'an aptitude or disposed potency' for assumption.

At one point, the Summa highlights an additional feature required for being a person: independence. An objector worries that the notion of existing per se - the mark of personhood in rational creatures - requires not being united to anything

37 Augustine, De genesi ad litteram, IX, c. 18, n. 34, ed. I. Zycha, CSEL, 48/1 (Prague; Vienna: F. Tempsky; Leipzig: G. Freytag, 1894), p. 293.12-15.

38 SH IV, In1, Tr1, Q4, Ti1, C3, Ar4 (n. 53), Ad obiecta 5, p. 79a. 
else. ${ }^{39}$ The Summa's reply: existing per se requires not being dependent on anything else; but it does not require failing to be united to anything else. But 'the Son of God in this union is a per se being, because his hypostasis or person does not depend on the human nature. ${ }^{40}$ The Summa does not go on to make the further, related, claim, that there is a sense in which the human nature depends on the divine person - understandably, because on the face of it dependence is a created relation, and the Summa's view is that there is no such thing in the case of the Incarnation. As we shall see, however, this move was quickly made by those of the Summa's earliest readers who disagreed with the authors on this issue.

It is worth noting something that this account leaves unclear. The characterizations of subsistence thus far offered are all negative: failing to be communicated, failing to be hypostatically dependent. It is not clear whether these state merely necessary conditions for subsistence, or necessary and sufficient conditions. As we shall see, Scotus - who was clearly familiar with these portions of the Summa - takes a stand: they are necessary and sufficient. And the account does not make it clear whether or not that lack of an aptitude is supposed to be merely privative, or whether it involves too an aptitude for subsistence. As we shall likewise see, this became a small bone of contention among the Franciscans too.

\section{Thomas Aquinas}

\section{The Hypostatic Union}

The closest and most immediate follower of the Christology of the Summa is not a member of the Franciscan order, but rather the Dominican Thomas Aquinas. What is most distinctive of the Summa's view, as I see it, is the claim that the union between the human nature and the divine person is immediate. This insight forms the central pillar of Aquinas' account of the metaphysics of Christology. He argues that the union cannot be accidental, on the grounds that

\footnotetext{
That which comes after complete esse comes accidentally unless it is drawn into the communion of that complete esse (nisi trahatur in communionem illius esse completi) (...). But the Word of God had, from eternity, complete esse according to hypostasis or person, and the human nature came to him in time - not assumed to one esse as that belongs to nature (as the body is assumed to the esse of the soul), but to one esse as that belongs to hypostasis or person. And for this reason the human nature is not united to the Son of God accidentally. ${ }^{41}$
}

39 SH IV, In1, Tr1, Q4, Ti2, C1 (n. 57), arg. 1, p. 82a.

40 SH IV, In1, Tr1, Q4, Ti2, C1 (n. 57), Ad obiecta 1, p. 84 .

41 Aquinas, $S T$ III, q. 2, a. 6 ad 2. All references to Aquinas are to the text available at https://www. corpusthomisticum.org/iopera.html. 
Here, in place of the Summa's claim that the human nature is drawn into the communion of the unity of the person, Aquinas claims that the human nature is drawn into the communion of the esse of the person. This provides Aquinas with a way of theorizing the union that is not open to the Summa, since Aquinas has a carefully worked out philosophy of the relation between esse and nature into which the case of the Incarnation can slip more or less seamlessly. ${ }^{42}$

As he sees it, there is a distinction between (individual) nature and esse in every creaturely case. Thus, Aquinas holds that there is a sense in which such an individual substance is a composite of essence and esse: 'Since in God alone is his esse his quiddity, it is necessary that, in any creature, be it corporeal or spiritual, there is found quiddity or nature and its esse (...) and thus [a creature, be it corporeal or spiritual,] is composed from esse, or that by which it is (quo est), and that which is (quod est) ) $^{33}$ - where, clearly, 'that which is' is essence, individualized and actualized in virtue of its relationship with its esse. This passage gets us composition. Elsewhere, Aquinas argues for distinction too: 'it is clear that esse is other than essence or quiddity - unless perhaps there is something whose quiddity is its esse. ${ }^{44}$ In the Christological case, the human nature lacks its proper esse, and receives instead the divine esse. And this is what it is for the human nature to be hypostatically united to the divine person. Hence Aquinas' famous view that there is only one esse in Christ. ${ }^{45}$

In line with this, Aquinas is clear that the union between the human nature and the divine person is immediate:

In the union of the human nature to the divine, there cannot fall a medium formally causing the union, to which the human nature would be joined before being joined to the divine person: just as between matter and form there does not fall a medium in esse which is in matter before substantial form is, otherwise accidental esse would be prior to substantial esse, which is impossible. So between nature and suppositum there cannot fall any medium in the way outlined, since each conjunction is to substantial esse. ${ }^{46}$

Again, the notion of union in esse allows Aquinas to provide something closer to a theory of the hypostatic union than the authors of the Summa manage. Here, it is the conjunction of the human nature with the 'substantial esse' of the divine person that explains the lack of a 'medium of necessity' (to use the language of the Summa).

42 Aquinas uses the image of grafting, but not in such a way as to allow it to model the hypostatic union, or to do any metaphysical work. In Sent. III, d. 1, q. 1, a. 1 c: 'The incarnation is compared to grafting: for just as, in a case of grafting onto a trunk in which there was one branch by nature, another branch is added by grafting, so in the same person in which there was by nature the divine nature, there is a human nature by union. But it is impossible for God and a creature to come together in one genus or species, although it is possible by analogy.'

43 Aquinas, In Sent. I, d. 8, q. 5, a. 1 c.

44 Aquinas, De ente, c. 3.

45 See Aquinas, ST III, q. 17, a. 2.

46 Aquinas, In Sent. III, d. 2, q. 2, a. 2, qc. 2 c. 
Aquinas agrees with the Summa that this communion in esse is brought about by a divine action, with a corresponding passion in the human nature. ${ }^{47}$ The Summa argues for two further related claims: first, that there is no created relation between the human nature and the divine person; and secondly, that there is no created relation between the human nature and the divine nature. Aquinas, as we have seen, holds that the first union is achieved by communion in esse. But he holds that the result of this union is a created relation in the human nature with the divine nature as its end term. ${ }^{48}$ His reason is that the union began to be in time, and thus requires a change on the part of the creature. ${ }^{49}$ Presupposed here, I think, is that the union of the natures cannot be a kind of uncreated communion (the divine nature is not communicated to the human in the way that the divine esse is): it is, thus, something created.

\section{The Nature of Subsistence}

There is another small but noteworthy difference between Aquinas and the authors of the Summa too. According to the latter, as we have seen, dignity is taken to be one of the defining features of persons. Aquinas abandons this last vestige of legally-inspired definitions of 'person'. An objector reasons that since 'personhood pertains to dignity,' it follows that Christ's human nature must be a person given that it is 'not of less dignity in Christ than in us. ${ }^{50}$ Aquinas' reply subordinates dignity to subsistence, and makes lack of subsistence the Christologically salient feature of Christ's human nature:

Personhood necessarily pertains to the dignity and perfection of a thing to the extent that it pertains to the dignity and perfection of something that exists per se, which is understood in the name of person. But it is of greater dignity for something that it exist in something of greater dignity than itself. For this reason it follows that human nature in Christ is of greater dignity than in us, since in us it exists per se as it were, and has proper personhood, whereas in Christ it exists in the person of the Word..$^{51}$

Here personhood is associated not with dignity but with its absence.

I think it likely, however, that Aquinas would agree with the authors of the Summa in those sections in which they maintain that Christ's human nature is incommunicable. Having quoted Boethius' definition of person (as 'individual substance of rational nature'), ${ }^{52}$ Aquinas includes incommunicability in the scope of in-

\footnotetext{
47 Aquinas, ST III, q. 2, a. 7 c.

48 Aquinas, ST III, q. 2, a. 8 c.

49 Aquinas, ST III, q. 2, a. 7 sed contra and c.

50 Aquinas, ST III, q. 2, a. 2 obj. 2.

51 Aquinas, ST III, q. 2, a. 2 ad 2.

52 See e.g. Aquinas, ST III, q. 2, a. 2 c.
} 
dividuality. ${ }^{53}$ And in line with this he associates communicability with the property of being 'predicable of many supposita. ${ }^{, 54}$ Christ's human nature does not have this feature. But Aquinas never says explicitly whether Christ's human nature is communicable or not.

\section{Bonaventure}

The situation in Bonaventure is more complex. First of all, the Summa is clearly more important for his overall Christology than it is for Aquinas': Bonaventure summarizes and develops a number of the discussions found in the Summa, as I shall show in a moment. But, secondly, Bonaventure expressly rejects the Summa's central insight, so masterfully developed by Aquinas: the immediacy of the union between human nature and divine person.

Bonaventure repeats precisely the Summa's account of the four kinds of union simpliciter (both natures destroyed; one nature destroyed, the other predominant; both natures preserved but mutually dependent; both natures preserved but one predominant), and, just like the Summa, sees the last one of these as relevant to the Christological case:

Only in this fourth kind of union is the divine nature united to the human: for since there is no repugnance between the divine nature and the human, there is no transmutation of the one to the other; and because there is no mutual dependence, there is no constitution of a third nature. But because there is the predominance of the one nature (i.e. the divine), it is necessary that the divine nature draws (trahat) the human nature to unity. But it cannot draw to unity of nature without transmutation and conversion. Therefore it is necessary that it draws it to unity of person, and that there is one and the same hypostasis of the divine nature and the human, so that the human nature is as it were grounded and substantified in the divine trunk (stipite). And for this reason the union is greatly like the union which is by grafting. It is perhaps (fortassis) on account of this that Blessed James says, 'Receive with meekness the engrafted Word. ${ }^{55}$

The presence of the quotation from the epistle of James shows that it is the Summa, rather than the Glossa, that is Bonaventure's source. His treatment of text, incidentally, is, in its apparent hermeneutical agnosticism, perhaps a bit more plausible than the Summa's. But with one exception the terminology is very close: the human nature is drawn to unity of person by the predominant nature (the divine). The exception is the talk of substantification, which is new, and which, as I shall show in a moment, Bonaventure understands very differently from the way the Summa construes the relation between the human nature and the divine person.

53 See Aquinas, ST I, q. 29, a. 3 ad 4.

54 Aquinas, ST III, q. 3, a. 1 ad 2.

55 Bonaventure, Commentaria in quatuor libros Sententiarum (In Sent.) III, d. 6, a. 2, q. 1 c, in Bonaventure, Opera omnia, 10 vols (Quaracchi: Collegium S. Bonaventurae, 1882-1902), vol. III, p. 158a. 
Like the Summa, Bonaventure speaks of a bond (vinculum) between the natures. ${ }^{56}$ But in sharp contrast to the Summa - which identifies this bond simply as the uncreated divine person - Bonaventure identifies it as a relation:

The divine person can be made a suppositum of human nature merely by a relation of the human nature to him: which relation does not imply anything new in the divine person, but only in the assumed nature, where there is not only denoted to be a relation (respectus), but also a unification (convenientia) in form: and this cannot be brought about without composition, or some change. ${ }^{57}$

The idea is that there is change or composition in the human nature. (I am not sure what precisely Bonaventure has in mind by 'convenientia in form': perhaps it is just the hypostatic union of the natures, but the language is not sufficiently specific to allow us to be sure.)

Elsewhere, Bonaventure is more specific, identifying this relation as one of a certain sort of dependence in the human nature:

Just as God, who is in a creature by essence, presence, and power, depends in no way on [the creature], but rather the creature depends on him as on a conserving and sustaining cause, so God, when he is in a rational creature by union, does not depend on [the creature], but rather, contrariwise, the rational creature depends on the divine hypostasis, and is sustained in him as nature is sustained in person..$^{58}$

A number of things emerge from this passage. The human nature depends on the divine person, not in a causal sense, but in the way that a nature depends on a person. And this dependence can be characterized as 'being sustained' - which I take it is synonymous with the substantification that Bonaventure talks about in a passage quoted above.

The relation that Bonaventure is talking about is construed by him in terms that resemble the Aristotelian category of relation: specifically, Aristotle's non-mutual relation in which the reality of the relation is found in merely one of the two relata. Thus, he gives a number of typical Aristotelian and Boethian examples of such relations: his beginning to be similar to someone in virtue of his being white by the mere generation of someone else white, 'without any change made in me [viz. Bonaventure];' or 'the similar example posited by Boethius, about left and right,' in which something begins to be to the left of something else merely in virtue of the motion of the other thing - merely Cambridge changes, as we would say. ${ }^{59}$

The analogy to creation is taken by Bonaventure to provide a way of characterizing the structural features of the dependence relation. In particular, like creation, it

56 See Bonaventure, In Sent. III, d. 6, a. 2, q. 2 ad 1 et 2 (III, p. 161b).

57 Bonaventure, In Sent. III, d. 6, a. 2, a. 1 ad 3 (III, p. 159a).

58 Bonaventure, In Sent. III, d. 1, a. 1, q. 1 c (III, p. 10a).

59 Bonaventure, In Sent. III, d. 1, a. 1, q. 1 ad 3 (III, pp. 10b-11a). The issue is treated similarly in Odo Rigaldus, In Sent. III, d. 6 (MS OBB lat. 208, fol. 369va). 
turns out that the dependence relation is not strictly speaking a categorial relation, since these really differ from their subject, and such is not the case for either kind of dependence (being created, being hypostatically sustained). Thus, Bonaventure claims that creation differs merely 'in reason (ratione)' from the creature itself; ${ }^{60}$ and I take it that the same is true of hypostatic dependence too. They are what later philosophers would label 'transcendental' relations: relations that belong in some sense to the substance of the thing. As Bonaventure puts it, 'the union of the natures is strengthened by such a bond (vinculo) that there never was brought about, nor could be, a separation. ${ }^{61}$ Still, we are in a very different Christological world from that of the Summa, or of Thomas Aquinas.

\title{
Duns Scotus
}

\section{The Hypostatic Union}

Scotus develops Bonaventure's insights about the dependence of the human nature with scrupulous metaphysical care. Here is the classic statement of his view:

\begin{abstract}
Although it is difficult to see that some dependence could be such, nevertheless all of this can be made clear in some way in a subject and an accident. For an accident has a two-fold relation to its subject or to its substance: namely, 1 . of what informs to what is informed (and this necessarily includes imperfection in the informed subject, in that [the subject] has some potentiality with respect to qualified (because accidental) act). It 2. has another [relation] as of what is naturally posterior to what is prior (on which it depends as on a subject, rather than as a cause, because if it has the subject as some kind of cause, it has it as a material cause, and this to the extent that it informs it). If therefore these two relations between an accident and a subject are distinguished from each other, the one is necessarily directed to a subject under the notion of imperfection in the subject, namely, potentiality, whereas the other does not necessarily posit any imperfection in [the subject], but merely natural priority and sustaining (substantificationem) with relation to the accident. And the relation which is the dependence of the human nature on the divine person is most similar to this [relation of accidental dependence]. ${ }^{62}$
\end{abstract}

Whereas Bonaventure simply gestures towards an analogy for the hypostatic union ('in the way that a nature depends on a person'), Scotus develops a fully-fledged

60 See Bonaventure, In Sent. II, d. 1, p. 1, a. 3, q. 2 (II, p. 34b).

61 Bonaventure, In Sent. III, d. 6, a. 2, q. 3 c (III, p. 163a-b).

62 Duns Scotus, Ordinatio (Ord.) III, d. 1, p. 1, q. 1, nn. 15-16, in Duns Scotus, Opera Omnia, eds. C. Balić et al., 21 vols (Vatican City: Vatican Press, 1950-2013), vol. IX, pp. 6-7. For extensive discussion of the passage, see my Communicatio idiomatum: Reformation Christological Debates, Changing Paradigms in Systematic and Historical Theology (Oxford: Oxford University Press, 2019), pp. 6-8; see too my The Metaphysics of the Incarnation: Thomas Aquinas to Duns Scotus (Oxford: Oxford University Press, 2002), ch. 5; for earlier medieval developments along the same lines, see Cross, Metaphysics of the Incarnation, chs. 3-4. 
model for the kind of relation he has in mind: the relation between a substance and an accident. Scotus' strategy is to distinguish different components in this relation, and then show which are applicable to the hypostatic union. Thus, the human nature cannot inform the divine person, since 'informing' is a technical term for a relation that involves the actualization of potentiality in a subject: and God is pure act, lacking all potentiality. But it can depend on the divine person in the way in which an accident depends on its substance. The relevant sense of 'dependence' is not causal, since every cause-effect relation between God and creatures has the entire Trinity as its end term, and only one divine person is incarnate.

Unlike causal dependence relations, the relevant dependence relation is sufficient to ground predication ('is man' predicated of the divine person, and accidents predicated of their substances):

\begin{abstract}
Although not every dependence is sufficient for making true a predication of what depends on what it depends on, that [dependence] which is of a nature, as communicable, on a suppositum, as hypostatically sustaining [the nature], is sufficient for making true a predication of the nature (thus dependent) of the suppositum on which it depends. This is clear in the case of an accident (thus dependent) on the suppositum of the substance on which it depends. ${ }^{63}$
\end{abstract}

The idea is that the relevant dependence/sustaining relations are sufficient for predication: if whiteness depends on Socrates, then it is true that Socrates is white, and if a human nature depends on the divine person (here labelled a 'suppositum', the technical Scholastic term for something that cannot depend in the relevant way), then it is true that that person is man.

In the text just quoted, Scotus introduces a third notion: communication. It turns out, in fact, that communication is the notion that distinguishes this kind of dependence from other forms: 'The unity or union of the human nature to the Word is a certain dependence, or consists in the kind of dependence that a nature, as communicable, has to some incommunicable subsistent. ${ }^{94}$ Scotus discerns two basic types of communication:

Something is said to be communicable either by identity, such that that to which it is communicated is it, or by information, such that that to which it is communicated is not it, but is by it. In the first way the universal is communicated to the singular, and in the second way form to matter. Thus a nature, as it is in itself and in its definition, is communicable in either way, that is to many supposita such that each of them is it, and also as that by which (quo), as a form, by which the singular or suppositum is a being in a quidditative way, or has a nature. And a suppositum is incommunicable by the opposed two-fold incommunicability. ${ }^{65}$

63 Duns Scotus, Quodlibetum (Quod.) q. 19, n. 15, in Duns Scotus, Opera Omnia, ed. L. Wadding, 12 vols (Lyons: Durand, 1639), vol. XII, p. 513.

64 Duns Scotus, Quod. q. 19, n. 3 (Wadding, XII, p. 493).

65 Duns Scotus, Ord. I, d. 2, p. 2, qq. 1-4, nn. 379-80 (Vat., II, pp. 345-46). See also Ord. III, d. 1, p. 1, q. 1, n. 49 (Vat., IX, pp. 21-22). 
The first kind of communicability - 'communicability ut quod' - is the relation that obtains between a whole individual essence and the suppositum of which it is an essence. Spelling this relation out requires a great deal of Scotist metaphysics that would distract me from my purpose here, so I ignore it in what follows. The second kind - let me label it 'communicability ut quo' - is that by which something 'is a being in a quidditative way': it is that which explains the fact that something is of a given kind, or has a particular accidental feature.

In contrast to both the Summa and Aquinas, then, Scotus holds that the human nature is communicable: it is the kind of thing that can be somewhat akin to an accidental property of a substance. And this, it seems to me, is much neater than the association of incommunicability and individuality which we found in the two 13thcentury texts just mentioned.

\section{The Nature of Subsistence}

Thus far the discussion has moved a long way from the Summa, and has developed precisely those lines of thinking in Bonaventure that are most remote from the Summa's own approach. But there is one striking element of Scotus' thinking that is evidently owed directly to the Summa: what it is for a nature to subsist. Here is what Scotus says:

We should distinguish between actual, possible, and aptitudinal dependence. And I call 'aptitudinal' that which is always in act (as it is of itself), in the way that a heavy object is naturally always at the centre [of the world], where it would always be (as it is of itself) unless impeded. And I call 'possible', unqualifiedly (absolute), that in which there is no impossibility from the repugnance or impossibility of the terms (and this possibility can be even with respect to a supernatural active power, not merely a natural one). And although the negation of actual dependence alone is not sufficient for what is proposed, for there is no created nature or entity to which it is contradictorily repugnant to depend on the Word), nevertheless the negation of aptitudinal dependence can be conceded in the created nature that is in itself personated in the Word, otherwise it would rest in a created person violently, as a stone rests high up violently. And thus this negation, not merely of actual but of aptitudinal dependence, completes the notion of person in an intellectual nature, and of suppositum in a created nature. Neither does this aptitudinal independence posit repugnance to actual dependence, because although there is no aptitude for depending in such a nature, there is an obediential aptitude, for that nature is in perfect obediential [potency] for depending through the action of a supernatural agent. And when this dependence is given to [the nature], it is personate by the personhood on which it depends; and when it is not given, it is formally personated in itself, by the negation, and not by something positive added to the positive entity by which it is this nature (haec natura) ${ }^{66}$

66 Duns Scotus, Ord. III, d. 1, p. 1, q. 1, nn. 45-47 (Vat., IX, pp. 20-21), text emended in accordance with both the majority of MSS and good sense. 
Scotus, then, takes a stand on an issue that the Summa leaves ambiguous: not only do natures fail to have an inclination for dependence; they have a positive inclination for independence.

The next thinker to consider this question explicitly is Ockham. He opts for the more neutral reading of the Summa on this point (though there is no evidence that he read the text directly): 'The assumed nature does not remain there [viz. united to the Word] violently, because it does not have an inclination to the opposite, which is required for something's being violent (...). The reason is that nothing is properly inclined to something unless that thing is positive ${ }^{97}$ - that is to say, unless the item to which the inclination is directed is positive. And here, I think, we see the end of the tradition of the Summa Halensis in medieval Franciscan Christology.

67 William of Ockham, Reportatio III, q. 1, in Ockham, Opera Theologica, eds. I. Lalor et al., 10 vols (St Bonaventure, NY: St Bonaventure University, 1967-86), vol. VI, p. 37.17-19, 23-24. 